\title{
Use of Competitive Intelligence Tools in Corporate Companies
}

\author{
Martin Mabeifam Ujakpa, Andriana Lupandu, Lucy Kiana and Symon Nyalugwe
}

\begin{abstract}
This study investigated the use of Competitive Intelligence tools by corporate companies in Namibia. Applying a mixed methodology and stratified random Sampling, data was collected from 98 respondents from five Namibian corporate companies. Linear regression analysis of the data show that there is low correlation between formulation of strategy, decision making and competitive intelligence while customer satisfaction, return on investment and competitive advantage have moderate correlation. The study found that Namibian companies are aware of and use competitive intelligence tools. Competitive intelligence tools used include SWOT Analysis, Market Research, Competitor Analysis, Competitor profile, Benchmarking, Value Chain, Boston Consulting Group Indicator \& warning analysis, and Michael Porter's five forces. The most used is Market Research and the least used is Michael Porter's five forces.
\end{abstract}

Keywords - Competitive Intelligence, Corporate Companies, Namibia, Tools.

\section{INTRODUCTION}

Major Corporation in the world trade globally and as a result, compete with local companies in the local companies' locality of operations. As at 2017, a little less than $10 \%$ of these major corporations controlled more than $80 \%$ all profits generated in the world [10]. Major corporations in the world are very large and well established entities. They have very good revenue, resources and expertise to operate globally. They usually employ between 15000 to a 100000 employees. Companies that fall in this category include Apple, Alphabet, Microsoft, Berkshire Hathaway, Exxon Mobil, Amazon, Facebook, Johnson and Johnson, General Electric and China Mobile [10]. Others from whom we buy virtually every product from include Nestle, PepsiCo, Procter \& Gamble, Unilever, Coca-Cola, Mars, Mondelez, Kraft-Heinz Company, Danone, General Mills, Associated British Food and Kelloggs [7] [33].

Local companies see these corporations as a business threat as they have a competitive advantage over them when they enter their localities. To overcome the threat or survive the competitive advantage, local companies have to strategically respond to challenges, opportunities and risk in their environment. Namibian corporate companies that operate at a large scale and are capable of competing globally include Pupkewitz Holdings, Bank Windhoek, Air Namibia, Agra, Namibia Breweries among others. The competition between these national companies and international corporations is

Martin Mabeifam Ujakpa, Ph.D Student, Faculty of Accounting and Informatics, Durban University of Technology, South Africa.

Andriana Lupandu, Lucy Kiana and Symon Nyalugwe, Durban University of Technology, South Africa. fierce, thus to effectively compete against these major global corporations, local companies must formulate business models that are competent to aid in strategic planning. This can be achieved by the use of competitive tools and techniques.

The environment of a business plays a major role in contributing to the profitability and growth of the business: hence the need for that business to gather and analyze its business environment information (both of the past and present) and to use it to predict future market trends. In view of the large amount of information in a business environment, it is challenging to analyze with ease, on time and accurately. To overcome this, managers may employ Competitive Intelligence tools, gather large amounts of information from their business environment, analyze it and on the basis of the results strategically plan to respond to the environment. According to [32] and [20] the quest for a company to obtain Competitive Intelligence tools is high when the company finds itself in a more competitive environment.

The use of competitive intelligence tools by companies is further necessitated by the uncertain nature of the business environment and by the fierce global competition. The Market environment is ever changing due to several factors such as globalization, new economic developments, non-ending changing consumer behavior, supply and demand, etc. [38]. All of these factors contribute to the large amount of market information and market trends making it more difficult to project market trends manually. There is therefore the need for the said market information to be analyzed and converted into intelligence that is usable by a businesses as confirmed by [1]. Use of available information by a company is not sufficient to make it survive market competition. However in cases where it survives, then the chances of it having a competition advantage is very low. As a result, [16] emphasized the need to distinguish between information and knowledge.

Reference to the stiff competition between national corporations and international corporations, there is need to investigate how national corporations use competitive intelligence tools to strategically position themselves in the market place. This study therefore investigated the use of Competitive Intelligence tools by corporate businesses in Namibia. The study specifically established competitive intelligence tools and techniques used in companies and examined how competitive intelligence is used in formulation of corporate strategies. The relationship between factors influencing the use of competitive intelligence was investigated. 


\section{LITERATURE REVIEW}

Different scholars define Competitive intelligence (CI) in different ways. [12] defines CI as a set of coordinated action research that enables useful information to be distributed to stakeholders to make informed decisions and carry out actions effectively. [28] defines CI as the act of collecting, processing and analyzing information from and about the internal and external or competitive environment in order to help decision-makers in decision-making and to provide a competitive advantage to an enterprise. The Society of Competitive Intelligence Professionals(SCIP) define $\mathrm{CI}$ as "the process of ethically collecting, analyzing and disseminating accurate, relevant, specific, timely, foresighted and actionable intelligence regarding the implications of a business environment, an organization's competitors and the organization itself [30]. The definition by SCIP was further echoed by [26] and [8] in their studies. As a result, this study adopted the definition by [30].

CI aims at creating knowledge from information that is widely accessible in other to reduce uncertainties in managerial decisions. It does not only help to anticipate risk and identify opportunities, but also aid in implementing winning strategies against competitors. Additionally, it involves using public sources of data on competition, competitors and the business market environment, whereby data is transformed through analysis into intelligence, [17].

Several studies conducted to identify stages in the CI Process include [38][3] and [2]. To effectively implement CI, an organization needs to set CI objectives, collect and organize data, analyze and interpret data and finally disseminate the intelligence from the analyzed data. This is illustrated in Fig 1.

Several studies on CI have been conducted to date to investigate the awareness and practicality of the CI process in some countries such China [34], Japan [27] Austria, [25] North America [23] and South Africa [6]. Most of the studies concluded that Competitive Intelligence aided companies to anticipate threats and opportunities in the market place.

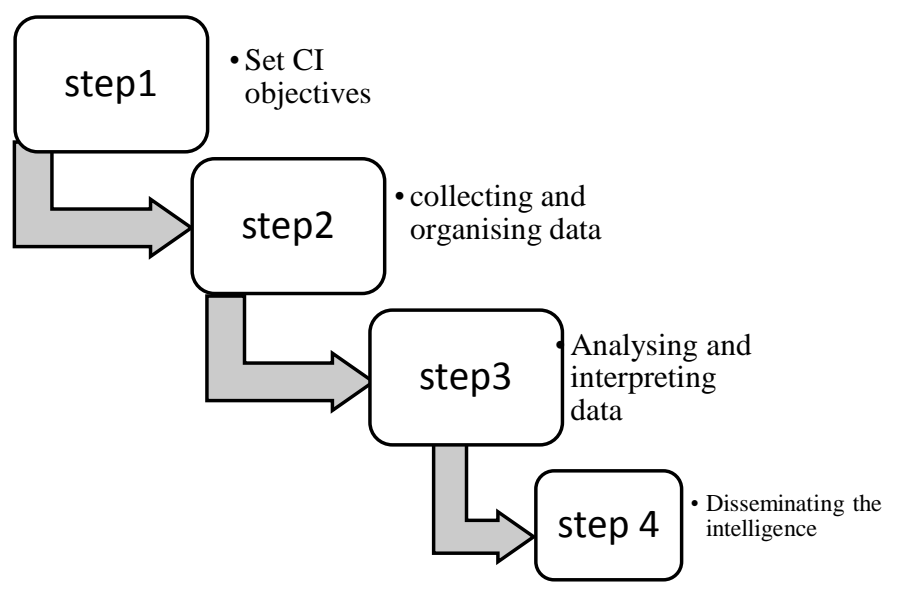

Fig. 1: Competitive Intelligence process.

Other countries in the world where $\mathrm{CI}$ is used by companies include France [31] Spain [35] UK [38], Sweden [13], Germany [18].
Most of the studies above concluded that CI ensures better decision making for the management. Notwithstanding the above, companies in some countries are still not using CIs. Among countries where companies don't use CIs include Serbia. In Namibia, the Tourism Industry is one of the sectors that uses CI tools to translate information into intelligence to enable various companies in the sector to forecast their income and expenditure relating to transport, accommodation, etc. The CI processes in Namibia are made possible by BMI research Group Company as reported in the Namibia Tourism Report. The intelligence is very useful to cooperation as it enables them access more recent information on market opportunities, threats and investment including future risk, insight \& emerging trends.

Methods and tools for carrying out competition analysis include Porter's five forces model, SWOT analysis, Value Chain Analysis, BCG Matrix, market research, competitors profile, customer value chain analysis and competitors technology, employees and CI department [37] [24] [19].

[22] created a business strategic tool that analyses the industry attractiveness, profitability and the factors that impacts business environment. This model is essential to perform the competitor's analysis as it helps managers to understand the dynamics or the business structure. It enables managers to reveal the strategies of the competitors on how they make their decisions, profits and business operations. The model identifies five forces of competitiveness which makes up the competitive environment. These are: Existing competitors, Threats to new entrants, bargaining power of suppliers, bargaining power of buyers and, last but not least, the threas of substitutes products or services.

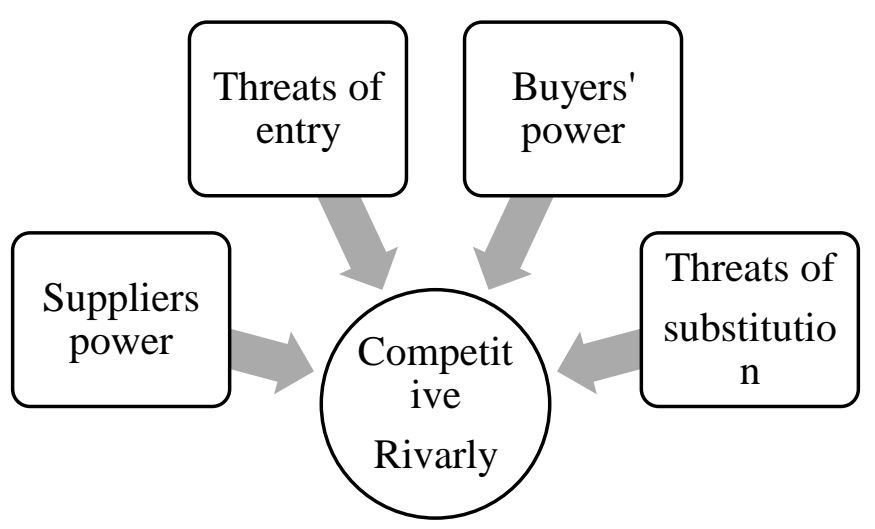

Fig. 2: Porter's five forces of competitiveness model

The SWOT analysis framework was originated by [14] and cited by [21]. It is a useful business tool used to analyze areas of the business such as the Strength, Weakness, Opportunities and Threats. This tool is basically used for strategy formulation by business organization because it include both internal factors affecting the business such as its strength and weakness and the external factors such as the opportunities and threats emerging from the market. Another benefit derived from the use of this framework is, it helps the business to create its own identity by promoting their strength and be able to identify and grab 
opportunities emerging from the market. SWOT analysis can also be used to formulate strategy, get a clear understanding of the competitors that will give the business a competitive position.

The Boston Consulting Group (BCG) matrix is one of the marketing tool that analyzes the product portfolio. The matrix categorizes the product into one of four different areas based on the market share and market growth as shown in Fig 2. The BCG matrix aims to optimize the cash flow from the product porfolio. The BCG growth share matrix display three elements of information for each product, product sales volume, market growth rate and relative market share.

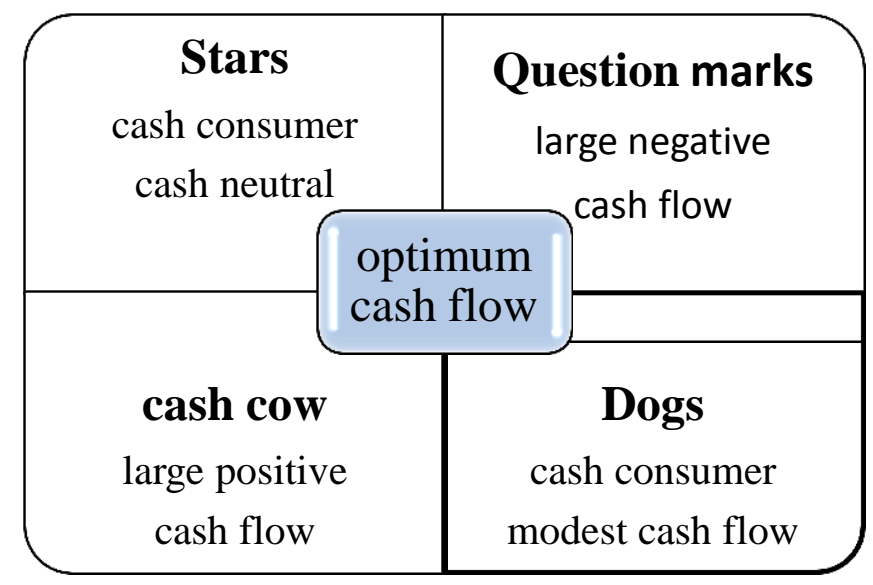

Fig. 3: The Boston Consulting Group (BCG) Matrix.

The BCG matrix is divided into four quadrants. The lower left represent cash cows, products that have dominated the market share, the lower right represent the dogs or loss leaders owning a small market share and which do not contribute much to the market share. The two top quadrants represent high growth markets, divided into stars, which have a dominant market share and the other quadrant is the question mark for the products entering the market. This tool helps to identify products that are good investment for the organization and direct the managers where to invest to maintain or grow the market share.

Market Research is defined as the systematic gathering and interpretation of information about individuals and organizations. It uses the statistical and analytical methods and techniques of the applied social, behavior and data sciences to generate insights and support decision making by the providers of goods and services, governments, nonprofit organization and general public, [15]. Marketing Research is conducted for a specific objective, trying to find a solution to arising issues. It is a systematic process and thus, ensure objectivity in all scientific processes to prevent losing focus. The choice of the methodology for the collection of data must be justified and enables the research to present results in a way that will help management during decision making.

The systematic process of this activity is quite important to enhance the success of a business. Therefore it should not be regarded as a once off activity but a continual activity. Market research plays a role in helping the business to keep up with the market trends and maintain a competitive advantage over competitors. Market research provides the company with timely information that will help to reduce business risk and help to spot sales opportunity hence aid the company to plan and execute a proper strategic plan.

[39] Define Competitors' Profile Matrix (CPM) as a tool that aids a company to assess its business against major competitors by using critical success factors for that industry. CPM is beneficial as it provides Key Success Factors (KSF) that can be used to identify major competitors and rate them using the CPM [9]).

\section{Methodology}

The study applied a mixed methodology. Through the qualitative approach, data was collected to comprehend and explain how competitive intelligence operates in the Namibian corporate sector. The quantitative approach enabled researchers to perform correlational analysis on the dependent and independent variables to establish the relationship between them.

The study population included employees, managers and executive managers from Air Namibia, Pupkewitz Holdings, Bank Windhoek, Agra and Namibia Breweries Limited. Why this companies. Together they were 5226 persons in the study population. Applying the [4] sample deterministic formula with an error margin of $10 \%$, a sample of 98 was arrived at. Due to the different population sizes of the different companies involved in the study and to justify the sample size for each company, a stratified random sampling was applied based on the percentage that each population formed in the entire population. The strata of sample size and population for each company is shown in Table 1 below.

TABLE I: POPULATION AND SAMPLE SIZE BY COMPANY

\begin{tabular}{|l|l|l|}
\hline Company name & $\begin{array}{l}\text { Population by } \\
\text { Company }\end{array}$ & $\begin{array}{l}\text { Sample size } \\
\text { by Company }\end{array}$ \\
\hline Air Namibia & 692 & 12 \\
\hline $\begin{array}{l}\text { Pupkewits } \\
\text { Holding }\end{array}$ & 1600 & 30 \\
\hline Bank Windhoek & 1494 & 28 \\
\hline Agra & 700 & 13 \\
\hline $\begin{array}{l}\text { Namibia } \\
\text { Breweries }\end{array}$ & 740 & 14 \\
\hline Total & $\mathbf{5 2 2 6}$ & $\mathbf{9 8}$ \\
\hline
\end{tabular}

Using questionnaires and face to face interview, data was gathered from 98 research subjects in the five companies.

The study analyzed the data using the Linear Regression $\left(R^{2)}\right.$ for the following reasons, firstly, it examined the relationship between multiple independent variables and one dependent variable to determine the extent to which the independent variable predict a dependent variable. Secondly, it forecasts the impact of any changes in the independent variable and thirdly, it helps to predict the future trends and values.

\section{ANALYSIS AND DISCUSSION}

Fig 3 show that respondents in the research hold different positions: 2 as board members, 8 as directors, 19 as managers' and 69 as employees. The variation in respondents ensured that varied information was collected enhance the study's validity and reliability. The different level of expertise of employees also ensured that different skills of the staff members was 
considered, enabling the study to yield trustworthy data and gave the researcher an opportunity to explore and explain the phenomenon at different level of the organization.

Fig 3 also shows the departments that participated in the study from the five companies of interest. Through this the study the study was able to establish if all department use Competitive intelligence or only some do. The results shows that, Sales department use CI more, followed by Marketing, Research \& Development and Consulting. Findings of [17] and Vella (2002) supports the use of competitive intelligence across departments as it coordinates various functions across different departments and transform information into actionable intelligence.

To ensure that the study was representative of a number of business environments and not just one, the study population was re-categories into four: Retail/Wholesalers, Manufacturing, Transport and banking. With the re-categorization, the study was certain of finding out about C.I use in the four business environment in Namibia. See the re-categorization fig xxx below.

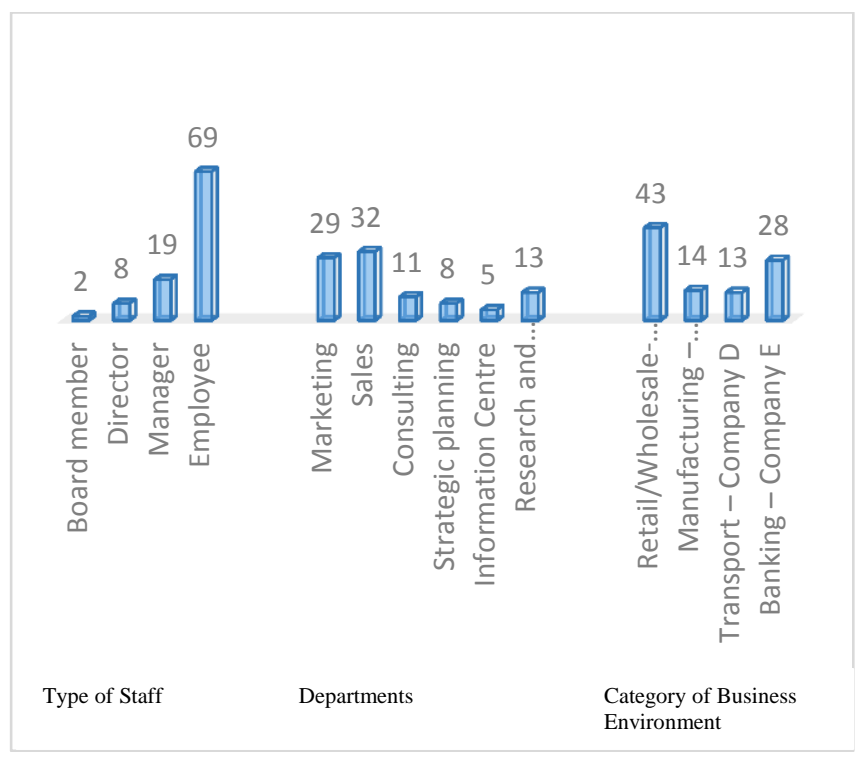

Fig. 4: Background of Respondents

In Fig 4, 47\% of respondent indicated that competition is very intense in the business environment in which their company operate and as a result they work hard to stay ahead of their competitors. 50\% of the respondents indicated that competition is intense and only 3\% said it was not intense. Fig 4 also show that majority of the companies own medium to large part of the Market share in their business environment making them to dominate and influence the industry. These companies are large corporations in Namibia and hence occupy about $80 \%$ of the market share: thereby leaving small and medium enterprises with a small chunk of the market share. Results in Fig 4 also show that most companies' market shares are either increasing or constant. However a small percentage of companies have their market share decreasing. In general, it can be concluded that most companies are performing well in their industry.

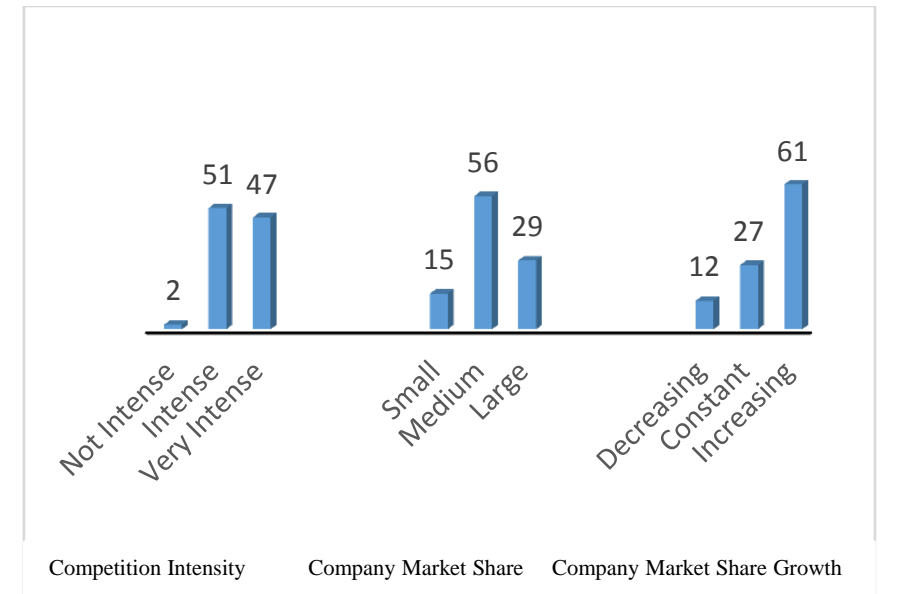

Fig. 5: Nature of Market and Competition

In response to whether they use competitive intelligence tools and techniques, $79 \%$ of the corporate companies indicated that they use it. 3\% indicated that they don't use competitive intelligence and $18 \%$ were not sure if they uses C.I. tools or not. From the analysis, it's found that many business in Namibia use more than one of the commonly used Competitive Intelligence analytic tools. This shows that, activities are planned accordingly and information is used at its best, giving substantial evidence to why businesses are growing strong regardless of the intense competition in their industries.

Fig 5 shows the commonly used competitive intelligence tools in Namibia. Market Research and SWOT Analysis are the commonly used followed by competitor analysis and Competitor profile and Benchmarking. These tools are mostly used to study the business environment and competitors. Studies of Priporas et al. (2009) in Greece and [19] in Tunisia confirm that the said $\mathrm{CI}$ tools above are the most commonly used.

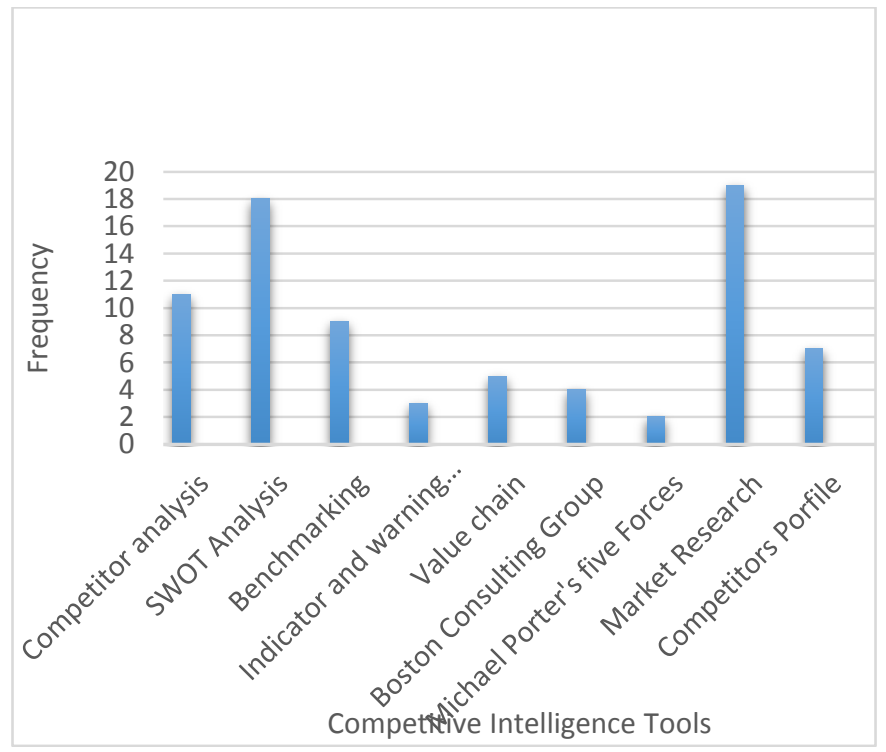

Fig. 6: Competitive Intelligence Tools

The study identified methods by which companies implement CI tools: Trial \& error, planned, as per project or outsourced. The most frequent method used are planned method (39\%) and per project (37\%) followed by trial \& error $(19 \%)$ and outsourced (5\%). On use of Competitive Intelligence tools as a monitoring system, the study found that 
companies' uses CI tools tool to monitor mostly customers and competitors, followed by business environment, technology, trends and business partner(s). This is indicated in fig 6 .

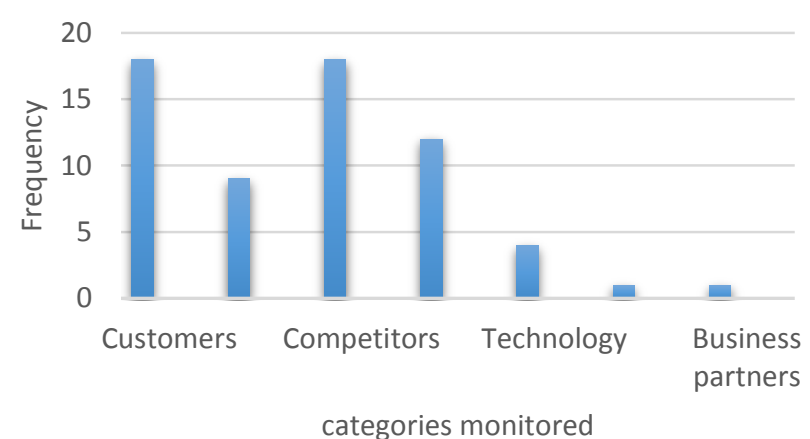

Fig. 7: Competitive Intelligence as a Monitoring Tool

On the primary use of CI tools, managers indicated that, it enables them to formulate strategies, make decisions, plan operations, position their companies in the market and finally enable them to identify social change. It also enables managers to identify early warning signs and opportunities and hence prevent their companies' from suffering any shock. Fig 7 shows that as a company use the C.I tools, the factors associated with increasing value and effectiveness show a positive correlation with the analytic tools. Studies by [38], [3], [29] and [12] confirms this.

\section{The relationship between the use, effectiveness and value of $C . I$ in the organisation.}

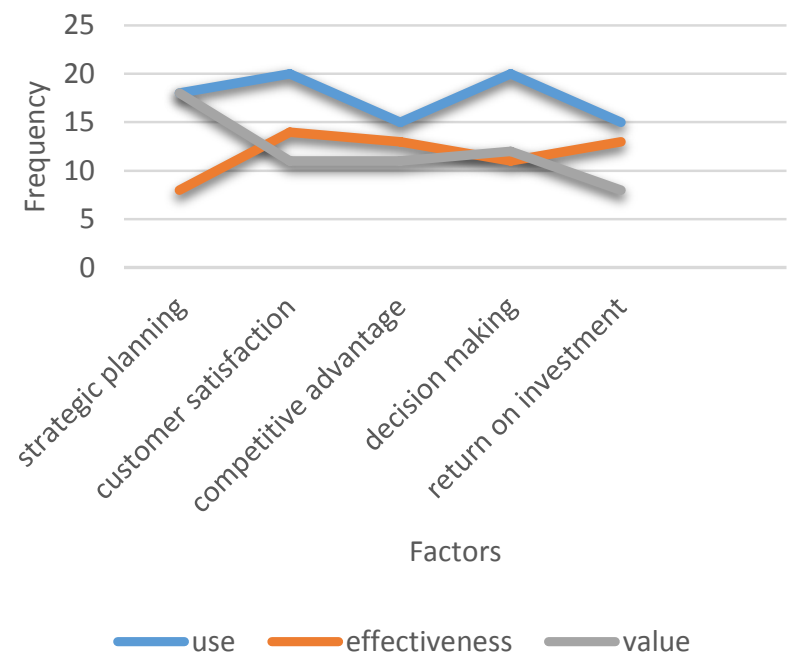

Fig. 8: Relationship between use, effectiveness and value of CI in organizations

From the study results, the following factors influenced the use of CI: Formulating strategy, Decision making, Operational planning, Market positioning, Communication, Customer satisfaction, C.I. Productivity, Return on investment, increased revenue, financial goal met, Creates competitive advantage,
Predicts future behavior, Launch products and Identify social \& cultural change. As in Table 2, five factors that stood out as main reasons why companies use Competitive Intelligence include formulation of strategy for the company, making decision, customer satisfaction, return on investment and competitive advantage. Results of regression analysis on these five factors is shown in Table 2.

Table 3 indicate a very low correlation between C.I and formulation of strategy as $\mathrm{R}$ value in the model summary is 0.083 , represent a simple correlation between the dependent and independent variable. The P-value of 0.894 is greater than 0.05 hence the regression model is insignificant to predict the outcome variable. Using the unstandardized coefficient value $(\mathrm{B}=21.125)$, the regression can be written as C.I. $=21.23-$ 0.05 (strategy formulation).

TABLE II: FACTORS ON WHY COMPANIES USE COMPETITIVE INTELLIGENCE

\begin{tabular}{|l|l|l|l|l|l|}
\hline Major Factors & $\begin{array}{c}\text { Company } \\
\text { A }\end{array}$ & $\begin{array}{c}\text { Company } \\
\text { B }\end{array}$ & $\begin{array}{c}\text { Company } \\
\text { C }\end{array}$ & $\begin{array}{c}\text { Company } \\
\text { D }\end{array}$ & $\begin{array}{c}\text { Company } \\
\text { E }\end{array}$ \\
\hline $\begin{array}{l}\text { Formulation of } \\
\text { strategy }\end{array}$ & $35 \%$ & $19 \%$ & $13 \%$ & $26 \%$ & $7 \%$ \\
\hline $\begin{array}{l}\text { Decision } \\
\text { making }\end{array}$ & $13 \%$ & $25 \%$ & $10 \%$ & $29 \%$ & $19 \%$ \\
\hline $\begin{array}{l}\text { Customer } \\
\text { satisfaction }\end{array}$ & $15 \%$ & $22 \%$ & $30 \%$ & $18 \%$ & $15 \%$ \\
\hline $\begin{array}{l}\text { Return on } \\
\text { investment }\end{array}$ & $30 \%$ & $19 \%$ & $15 \%$ & $17 \%$ & $12 \%$ \\
\hline $\begin{array}{l}\text { Competitive } \\
\text { advantage }\end{array}$ & $40 \%$ & $18 \%$ & $7 \%$ & $17 \%$ & $18 \%$ \\
\hline
\end{tabular}

TABLE III: REGRESSION ANALYSIS OF FACTORS ON WHY COMPANIES USE

\begin{tabular}{|c|c|c|c|c|c|c|}
\hline Variable & $\begin{array}{l}\text { R-Val } \\
\text { ue }\end{array}$ & $\begin{array}{l}\mathbf{R} \\
\text { Square } \\
\text { Value }\end{array}$ & $\begin{array}{l}\text { P-Val } \\
\text { ue }\end{array}$ & $\begin{array}{l}\text { B - } \\
\text { Value }\end{array}$ & Significance & $\begin{array}{l}\text { Regression } \\
\text { Written as } \\
\text { (C.I. =) }\end{array}$ \\
\hline $\begin{array}{l}\text { Formulation } \\
\text { of Strategy }\end{array}$ & 0.083 & 0.007 & 0.894 & 21.125 & Insignificant & $\begin{array}{l}21.23- \\
0.05\end{array}$ \\
\hline $\begin{array}{l}\text { Decision } \\
\text { Making }\end{array}$ & 0.085 & 0.007 & 0.892 & 21.519 & Insignificant & $\begin{array}{l}-0.079+ \\
21.5199\end{array}$ \\
\hline $\begin{array}{l}\text { Customer } \\
\text { Satisfaction }\end{array}$ & 0.803 & 0.645 & 0.102 & 38.86 & Insignificant & $\begin{array}{l}-0.95+ \\
38.86\end{array}$ \\
\hline $\begin{array}{l}\text { Return on } \\
\text { investment }\end{array}$ & 0.133 & 0.018 & 0.831 & 17.346 & Insignificant & $\begin{array}{l}0.143+ \\
17.346\end{array}$ \\
\hline $\begin{array}{l}\text { Competitive } \\
\text { Advantage }\end{array}$ & 0.568 & 0.323 & 0.318 & 13.07 & Insignificant & $\begin{array}{l}0.346+ \\
13.07\end{array}$ \\
\hline
\end{tabular}

Also there is a very low correlation between C.I and decision making as $\mathrm{R}$ value in the model summary is 0.085 , represent a simple correlation between the dependent and independent variable. The $\mathrm{P}$-value of 0.892 is greater than 0.05 hence the regression model is insignificant to predict the outcome variable. Using the unstandardized coefficient value $(\mathrm{B}=$ 21.519), the regression can be written as C.I. $=-0.079+$ 21.5199 (Decision Making).

\section{CONCLUSION}

The results revealed that the Namibian Companies are aware of the Competitive Intelligence tools. All five companies involved in study use some but not all of CI tools to transform their information into intelligence. CI tools used by companies, starting from the most frequently used to the least include SWOT Analysis, Market Research, Competitor Analysis, Competitor profile, Benchmarking, Value Chain, Boston Consulting Group Indicator and warning analysis and Michael Porters five forces. Previous studies that confirms this include studies by [24] and [19].

The quantitative linear regression analysis revealed that there is a correlation between strategy formulation and C.I, but it is very low in Namibian companies. The qualitative data analysis 
results also found same as various experts in the field of C.I indicated same.

On factors that influence use of CI, businesses identified five major factors (not exhaustive) that influence their use of C. I. These factors are strategy formulation, decision making, customer satisfaction, return on investment and competitive advantage. Findings of [38] and [3] confirm this as they concluded that C.I. help senior managers to devise strategies and plans to maximize competitive advantage for the company. Further linear regression analyses of these factors indicated a low a low correlation between the dependent and independent variables. This confirms that companies in Namibia are at an infant stage of implementing CI and this may be because it is a new emerging field. However further study need to be carried out to confirm this. Namibia is not the only country that is at the infancy stage of using C.I. According to [11], many countries also are also at the infancy stage of using C.I as 236 responses from 21 industries in the USA and Europe indicate so. The findings of the study has provided evidence regarding the use of Competitive Intelligence by Namibian companies.

\section{RECOMMENDATION}

Since only five companies were investigated, the researcher recommends that future studies include Small and Medium Enterprises. Also future studies should include additional business industries as this study considered only four.

\section{REFERENCES}

[1] Albescu F., Pugna I. \& Paraschiv D. R.(n.d). Business Competitive Intelligence - The Ultimate use of Information Technologies in Strategic Management. ICI Conference, Romania. Retrieved from: http://www.asecu.gr/files/RomaniaProceedings/01.pdf

[2] Bose, R. (2008). Competitive Intelligence Process and Tools for Intelligence Analysis. Industrial Management \& Data System. 108 (4), 510-528. https://doi.org/10.1108/02635570810868362

[3] Calof, J. \& Viviers, W. (2005). Competitive Intelligence in a Foreign Environment: German and Canadian firms compared. Multinational Enterprises, Foreign Direct Investment and Growth in Africa. Contributions in Economics, 209 - 225. https://doi.org/10.1007/3-7908-1610-8_9

[4] Cohen, L., Manion, L., \& Morrison, K. (2007). Research Method in Education. 6th Ed. London and New York: Routledge. https://doi.org/10.4324/9780203029053

[5] Creswell, J. W. \& Miller, D. L. (2000). Determining Validity in Qualitative Inquiry. Theory into Practice Journal, 39(3). https://doi.org/10.1207/s15430421tip3903_2

[6] De Pelsmacker, Muller M., Viviers W., Saayman A., Cuyvers L., Jegers M., (2005). Competitive Intelligence Practices of South African and Belgian Exporters. Journal of Marketing Intelligence \& Planning, 23 https://doi.org/10.1108/02634500510624156

[7] Durden T. (2018). These 11 Companies Control Everything You Buy. Retrieved from:

https://www.zerohedge.com/news/2018-12-08/these-11-companies-cont rol-everything-you-buy

[8] Ding L. (2009). Analysis on the Competitive Intelligence in Business Management. IEEE Xplore. Retrieved from: https://ieeexplore.ieee.org/document/5447217/citations

[9] Fleisher \& Bensoussan. (2003). Managing Frontiers in Competitive Intelligence. London: Quorum Books.

[10] Grey A. (2017). These are the world's 10 biggest corporate giants. World Economic Forum. Retrieved from: https://www.weforum.org/agenda/2017/01/worlds-biggest-corporate-gia nts/

[11] Gilad, B. (1996). Business Blindspots: Replacing your company's Entrenched and Outdated Myths, Beliefs and Assumptions with the realities of today's Markets, Chicago, IL: Probus Publishing Company.
[12] Haddadi, H., Hui, P., \& Henderson, T., \& Brown. (2006). Targeted advertising on the handset: Privacy and security challenges. University of London, London.

[13] Hedin, H., (2004). Evolution of Competitive Intelligence in Sweden. Journal of Competitive Intelligence and Management, 2(3).

[14] Humphrey A. (2005). SWOT Analysis for Management Consulting. SRI Alumni Newsletter. SRI International. Retrieved from: https://universe.bits-pilani.ac.in/uploads/SWOT\%20Analysis.pdf

[15] ICC/ESOMAR, (2018). International code on market, opinion and social research and data analytics.

[16] Kahaner, L. (1997). Competitive Intelligence - How to Gather, Analyze and Use information to move your business to the top. Touchstone Rockefeller Center, New York.

[17] McGonale, J.J. and Vella, C.M (2002). Bottom line Competitive intelligence. Quorum Books: West Point.

[18] Michaeli, R. (2004). Competitive Intelligence in Germany. Journal of Competitive Intelligence and Management, 2(4).

[19] Nasri, W. (2011). Competitive Intelligence in Tunisian companies. Journal of Enterprise Information Management. https://doi.org/10.1108/17410391111097429

[20] Oubrich, M., Hakmaoui, A., Bierwolf, R. \& Haddani, M. (2018). Development of a Competitive Intelligence Maturity Model: Insights from Moroccan companies. J. Intell. Stud. Bus., 8, 25-36.

[21] Ommani, A. R. (2011). Strengths, weaknesses, opportunities and threats (SWOT) anlysis for farming businesses management: Case of wheat farmers of Shadervan District, Shoushtar Township, Iran. African Journal of Business Management, 5(22), 9448-9454.

[22] Porter, M. E. (1980). Competitive Strategy: Techniques for analyzing industries and Competitors. New York. NY: Free Press.

[23] Prescott, J. E. \& Bhardwaj, G. (1995). Competitive Intelligence Practice: A Survey. Competitive Intelligence Review, 6. https://doi.org/10.1002/cir.3880060204

[24] Priporas, C.V., Gatsoris, L., \& Zacharis, V. (2009). Competitive Intelligence activitIES: Evidence from Greece. Marketing Intelligence \& Planning.

[25] Roitner, A. (2008). Competitive Intelligence in Austria: An empirical study. Universitad Wien, Mag. rer. Retrieved from: http://othes.univie.ac.at/756/1/05-19-2008_0003246

[26] Rouach, D. and P. Santi. (2001). Competitive Intelligence Adds Value: Five Intelligence Attitudes. European Management Journal, (19)5, pp. 552. https://doi.org/10.1016/S0263-2373(01)00069-X

[27] Sugasawa, Y. (2004). The Current State of Competitive Intelligence Activities and Competitive Awareness in Japanese Businesses. Journal of Competitive Intelligence and Management, 2(4)

[28] Tahmasebifard H. and Wright T. L. (2018). The Role of Competitive Intelligence and its Sub-types on Achieving Market Performance. Cogent Business \& Management, 5(1). https://doi.org/10.1080/23311975.2018.1540073

[29] Santos, M., \& Correia, A. (2010). Competitive Intelligence as a Source of competitive Advantage: An Exploratory study of the Portuguese Biotechnology Industry. Proceedings of the European conference on Knowledge Management, Famalicao, Portugal.

[30] SCIP (2018). Society of Competitive Intelligence Professional. Retrieved from, http://www.scip.org/.

[31] Smith \& Kossou (2008). The Emergence and Uniqueness of Competitive Intelligence in France. Journal of Competitive Intelligence and Management, 4(3).

[32] Salguero C. G., Gámez A. F. M, Fernández A. I. \& Palomo R. D. (2019). Competitive Intelligence and Sustainable Competitive Advantage in the Hotel Industry. Sustainability, 11. https://doi.org/10.3390/su11061597

[33] Taylor K. (2017). These 10 companies control everything you buy. Retrieved from:

https://nordic.businessinsider.com/these-10-companies-control-everyth ing-you-buy-2017-9

[34] Tao, Q. \& Prescot J. (2000). China: Competitive Intelligence in an emerging market environment, Competitive Intelligence and Management. https://doi.org/10.1002/1520-6386(200034)11:4<65::AID-CIR10>3.0. $\mathrm{CO} ; 2-\mathrm{N}$

[35] Tena, M.J. \& Comai, A. (2004). Competitive Intelligence in Spain: A situational appraisal. Journal of Competitive Intelligence and Management, 2(3). 
[36] Viori V. (2011). Social Media Changing the Competitive Intelligence Process: Elicitation of Employees Competitive Knowledge. Tampere University of Technology. Retreived from: https://tutcris.tut.fi/portal/files/5109627/vuori.pdf

[37] Wright, S., \& Fleisher, C.S. (2009). Competitive Intelligence in Practice: Empirical Evidence from the UK Retail Banking Sector. Journal of Marketing Management. https://doi.org/10.1362/026725709X479318

[38] Zenaide, V. \& Castro, L.T., (2015). Scenario of Business Practices in Competitive Intelligence within the Telecommunication Industry. African Journal of Business Management.

[39] Zimmerer, W. T., Scarbrough, N. M. \& Wilson, C. (2008). Essentials of Entrepreneurship and Small Business Management. 5th Ed. New Jersey: Pearson Education, Inc. 